\title{
Marta Widy-Behiesse
}

\author{
Uniwersytet Warszawski \\ Wydział Orientalistyczny \\ Zakład Islamu Europejskiego
}

\section{RÓWNOUPRAWNIENIE W MYŚLI ZACHODNICH INTELEKTUALISTEK MUZUtMAŃSKICH}

\author{
The issue of equal rights viewed by women Muslim intellectuals in Western Europe
}

\begin{abstract}
The idea of reforming Islam is gaining more and more popularity with West European and American Muslim intellectuals. Although the kind and magnitude of the suggested changes may vary, yet the necessity to alter the status of women in Islamic societies and communities is being widely admitted. In this context the studies and analyzes prepared by the Muslim women, who by exploring the sources of Islamic religion and legislation indicate the direction of such changes, deserve a special attention. By living in the Western Europe they rely on Muslim and European tradition alike, thus adding a new dimension to the discussion upon the role and position of women in Islam. The article deals with the pro equal rights activity undertaken by Amina Wadud, Leila Ahmed, Zahra Ali and Fadela Amara.
\end{abstract}

Keywords: gender, Europe, European Islam, Women's movement in Islam, feminism, Muslim feminism, Islamic feminism

\section{Wprowadzenie}

W powszechnej opinii muzułmanki są uciśnionymi kobietami, podległymi woli mężczyzn, ludźmi drugiej kategorii, którym w imię Allaha odbiera się prawo do wolności i godności osobistej. „Na Zachodzie panuje przekonanie, że kobieta w świecie islamu jest zniewalana i nie ma żadnych praw. Chusta na głowie muzułmanki i jej zasłonięta twarz są uznawane za relikty z minionej epoki"'. Obraz ten zastąpił, popularną jeszcze na początku zeszłego stulecia, wizję haremowej odaliski, wykreowaną w XIX wieku w ramach popularnego wówczas nurtu orientalizmu.

A. Wąs, Kobieta w islamie, Wiara.pl, 10.04.2009, http://religie.wiara.pl/doc/472173.Kobieta-w-islamie (dostęp: 21.11.2014). 
Zagadnienie pozycji i roli kobiet w społecznościach muzułmańskich staje się łatwym argumentem, mającym świadczyć o niższości cywilizacyjnej wyznawców islamu. Specjaliści natomiast zdają się traktować temat jako dość błahy czy też nadmiernie eksploatowany przez media, przez co w konsekwencji rzadko poddaje się go głębszej analizie. Wyjątkiem są rozważania Ewy Machut-Mendeckiej w książce Archetypy islamu ${ }^{2}$ oraz publikacja Kobieta $w$ literaturze i kulturze Egiptu ${ }^{3}$. Należy też wskazać książkę pod redakcją Marka M. Dziekana i Izabeli Kończak Kobiety Bliskiego Wschodu ${ }^{4}$. Ciekawym uzupełnieniem może być artykuł Seks, władza, pieniądze - rola kobiety w średniowiecznym społeczeństwie ismailickim ${ }^{5}$, choć jest to już znacznie bardziej zawężony temat ${ }^{6}$.

Dość ogólnie opracowania wskazują, że sytuacja kobiet muzułmańskich jest bardzo zróżnicowana i zależy od kraju, regionu, klasy społecznej i wielu innych czynników ${ }^{7}$. Zwykło się wspominać o wybitnych muzułmankach ${ }^{8}$, pojawiają się również nieliczne artykuły traktujące o feminizmie muzułmańskim ${ }^{9}$ i jego przedstawicielkach, między innymi o Nawal Saadawi i Fatimie Mernissi. Nieco bardziej analityczny jest artykuł Joanny Brzezińskiej na temat ruchu kobiecego w Egipcie ${ }^{10}$. Przy czym w świecie muzułmańskim działaczek na rzecz równouprawnienia jest wiele, a wydaje się, że obecnie przybywa ich z każdym dniem. Także ich perspektywa, cele, ideologia oraz metody działania są bardzo różnorodne, a wiele $\mathrm{z}$ nich nie nazywa siebie feministkami.

W opozycji do świata islamu Zachód kojarzy się z pełną wolnością, swobodą i równouprawnieniem oraz kolebką feminizmu. Może i słusznie, choć w Egipcie na

2 E. Machut-Mendecka, Archetypy islamu, Wydawnictwo Psychologii i Kultury Eneteia, Warszawa 2006.

3 K. Pachniak (red.), Kobieta w literaturze i kulturze Egiptu, Katedra Arabistyki i Islamistyki Uniwersytet Warszawski, Warszawa 2016.

4 M.M. Dziekan, I. Kończak (red.), Kobiety Bliskiego Wschodu, Wydawnictwo Ibidem, Łódź 2005.

5 A. Abbas, A. Maśko (red.), W kręgu zagadnień świata arabskiego, Uniwersytet im. Adama Mickiewicza, Poznań 2015, s. 387-405.

${ }_{6}$ Inne publikacje na temat kobiet i świata islamu to m.in.: B. Kowalska, Kobiety, rozwój, obywatelstwo w Haszymidzkim Królestwie Jordanii, Wydawnictwo Uniwersytetu Jagiellońskiego, Kraków 2013; eadem, Kontrola kobiecej cielesności. Refleksje o orientalizmie, fundamentalizmie i zastonie, w: J. Bator, A. Wieczorkiewicz (red.), Ucieleśnienie II. Między ciatem a tekstem, Wydawnictwo IFiS PAN, Warszawa 2008; eadem, Pteć, islam a zmiana spoleczna. Dylematy wspótczesnego dyskursu emancypacyjnego na Bliskim Wschodzie, w: A. Kapiszewski (red.), Świat arabski w procesie przemian. Zmiany społeczne i kulturowe oraz reformy polityczne, Księgarnia Akademicka, Kraków 2008.

7 Por. M. Bobako, Feminizm islamski. Niechciane dziecko islamu politycznego, „Praktyka Teoretyczna” 2013, nr 2 (8), www.praktykateoretyczna.pl (dostęp: 22.07.2015).

8 A.S. Nalborczyk, Dżihad genderowy, „Więź” 2014, nr 1 (655), s. 92-99.

9 E. Szczepankiewicz-Rudzka, An-nisayat - różne wymiary feminizmu $w$ świecie islamu, „Kultura i Wartości” 2014, nr 1 (9), s. 83-102.

10 J. Brzezińska, Islam i feminizm - ruch kobiet $w$ Egipcie na rzecz równouprawnienia kobiet, „Acta Universitatis Lodziensis. Folia Sociologica” 2011, nr 39. 
początku XX wieku rozwijał się ruch myśli zmierzającej do równouprawnienia kobiet, podobny nurt wyłaniał się w Tunezji, Turcji i Iranie ${ }^{11}$.

Czasem można też usłyszeć, iż ,(...) w świecie islamu uważa się, że wolność i samookreślenie kobiety na Zachodzie przekroczyło granice przyzwoitości. Kobiety zostają bezwzględnie wykorzystane przez mężczyzn, czego dowodem są choćby prostytucja i pornografia oraz sposób ubierania się niemuzułmanek"12.

Jak zatem wygląda sytuacja i postawy muzułmanek wychowanych na Zachodzie? Czy można mówić, że stanowią one awangardę muzułmańskiego wyzwolenia od patriarchalnego ładu społecznego?

\section{Feminizm w świecie islamu}

$\mathrm{Na}$ świecie początki ruchu na rzecz równouprawnienia kobiet sięgają połowy XVIII wieku, choć znacznie wcześniej pojawiały się już głosy i wystąpienia dotyczące roli i pozycji kobiet w ówczesnych społeczeństwach ${ }^{13}$. Jednak to myśl oświeceniowa i rewolucja francuska sprawiły, że na szerszą skalę zajęto się tym zagadnieniem, a powstające publikacje docierały do coraz szerszego grona odbiorców.

W połowie XIX wieku kobiety zaczęły się zrzeszać w celu osiągnięcia daleko idących zmian w układzie społecznym, ekonomicznym i politycznym swoich społeczeństw. June Hannam - profesor na Uniwersytecie Zachodniej Anglii i redaktor „Women's History Review” - zwraca jednak uwagę, że w tym początkowym okresie idee feministyczne rozwijały się wśród białych kobiet ${ }^{14}$. Rozpoczęty w ten sposób szeroki ruch feminizmu dzieli się na trzy fale (I fala - 1860-1920, II fala - lata 60 . i 70. XX wieku, III fala - od lat 90.) i dopiero w ramach ostatniej z nich znajduje się miejsce dla feminizmów: etnicznego, trzecioświatowego, latynoskiego, czarnego czy muzułmańskiego. Badacze zwracają uwagę, że metafora fal nie jest doskonała, może bowiem doprowadzić do pominięcia ważnych postaci i ich działań, jeśli ,przemkną się" pomiędzy wskazywanymi okresami ${ }^{15}$.

Ruchy feministyczne o charakterze etnicznym i religijnym powstały, ponieważ główny kierunek był zorientowany przede wszystkim na zaspokajanie potrzeb i ambicji białych kobiet z krajów szeroko pojętej cywilizacji Zachodu. Konieczne okazało się wypracowanie takich idei feministycznych, które będą uwzględniały specyfikę społeczeństw $\mathrm{z}$ innych części świata.

Zwykło się uważać, że ojcem feminizmu w kręgu cywilizacji muzułmańskiej był Qāsim Amīn (1863-1908), autor sztandarowej rozprawy Wyzwolenie kobiet (arab. Taḥrī al-mar 'a), w której intelektualista dowodzi, iż źródłem nierówności płci są lo-

11 Ówcześnie kraje te stanowiły część imperium osmańskiego.

12 A. Wąs, op. cit.

13 Na przykład Hildegarda z Bingen i Christine de Pizan.

14 J. Hannam, Feminizm, Zysk i S-ka, Poznań 2010, s. 21.

15 Ibidem, s. 25. 
kalne świeckie tradycje, a islam to religia wzywająca do wyrównania statusu przedstawicieli obu płci ${ }^{16}$. Przekonanie o istotnym wkładzie tego intelektualisty w rozwój doktryny równościowej w łonie islamu podważają między innymi Fatima Mernissi ${ }^{17}$ i Leila Ahmed. Ta ostatnia wskazuje, że dzieła Q. Amina i innych modernistów tej epoki powinno się zaliczać raczej do nurtu modernizacji, ewentualnie do grupy reformatorów, nie zaś protagonistów/protoplastów feminizmu, gdyż w istocie podejmowana tematyka dotyczyła zreformowania społeczeństwa na wielu płaszczyznach, a idee łączyły wątki nacjonalizmu, rozwoju kulturalnego, intelektualnego czy postępu gospodarczego w pogoni za osiągnięciami Zachodu, i to w tym kontekście pojawiały się też wątki kobiece. Analizując natomiast genezę feminizmu zachodniego, widać, że nie musi on być bezpośrednio uwarunkowany potrzebą ogólnych reform społecznych i intelektualnych ${ }^{18}$. Wśród pionierek ideologii zmierzającej do równouprawnienia L. Ahmed wskazuje Hudę Ša 'arāwī, Malak Ḥāfn̄̄ Nāṣif, Māi Ziyādę, Dorię Šafiq, Nawāl as-Sa 'adāwī, a także 'Alifę Rif 'at' ${ }^{19}$. Od chwili pojawienia się idei feministycznych w myśli muzułmańskiej pod koniec XIX wieku koncepcje te zawsze znajdowały swoich orędowników. Feminizm bywa jednak utożsamiany z zachodnim systemem wartości i odrzucany na fali ogólnej niechęci wobec zachodniego zepsucia moralnego i znienawidzonej westernizacji. ,Termin «feminizm» sam w sobie jest już obarczony negatywną opinią, widzi się w nim produkt z importu, czy wręcz narzucony przez Zachód koncept, często rozumiany w sposób ograniczony do stawiania w opozycji kobiet i mężczyzn oraz wrogi islamowi"20.

Celem niniejszego artykułu jest wskazanie kształtującej się nowej grupy feministek muzułmańskich żyjących na Zachodzie. Z tego względu pominiemy charakterystykę zróżnicowanej myśli feministycznej w świecie islamu, mimo że niezwykle pożyteczne i ciekawe byłoby rozważenie różnych, często sprzecznych, wizji feminizmu w łonie islamu. Samo zdefiniowanie, czy kobieta i mężczyzna są tacy sami, czy też różniąc się, są sobie równi, wymagałoby już szerokiego omówienia. Nie to jest jednak przedmiotem dociekań w tym artykule. Centralnym elementem będzie wskazanie podstawowych sfer działania oraz zaprezentowanie sylwetek najpopularniejszych, najaktywniejszych i najciekawszych działaczek na rzecz równouprawnienia, których opinie i postawy często budzą kontrowersje.

16 Q. Amin, Tahrir al-Mar'a, al-Qahira 1970; M. Abisaab, R.J. Abisaab, A Century after Qasim Amin: Fictive Kinship and Historical Uses of 'Tahrir al-Mara', http://www.aljadid.com/content/century-after-qasim-amin-fictive-kinship-and-historical-uses-tahrir-al-mara\#sthash.oZgWrFZP.dpuf (dostęp: 15.11.2014).

17 F. Mernissi, Beyond the Veil, Indiana University Press, Bloomington 1987, s. 14-15.

18 L. Ahmed, Women and Gender in Islam: Historical Roots of a Modern Debate, Yale University Press, New Haven 1992, s. 128.

19 Ibidem, s. 183.

20 N. Guessous Idrissi, Féminisme musulman, féminisme islamique ou féminisme en terre d'islam. L'exemple du Maroc, w: Existe-t-il un féminisme musulman?, L'Harmattan, Paris 2007, s. 98. 


\section{Feminizm islamski, muzułmański czy feminizm w świecie islamu}

Zanim przejdziemy do scharakteryzowania intelektualistek i aktywistek na rzecz równouprawnienia oraz ich poglądów, należy zdefiniować pojęcia, które będą się pojawiały w toku dalszych rozważań. Najistotniejsze jest wyodrębnienie nurtów feminizmu w ramach cywilizacji muzułmańskiej. Proponuję zdefiniować je następująco:

Feminizm islamski, rozumiany jako ruch zmierzający do utrwalenia w świadomości ogółu, że kobiety i mężczyźni, choć są sobie równi zarówno przed Bogiem, jak i w społeczeństwie, to ze względu na cechy charakterystyczne obu płci przypisane są im różne role, prawa, zalecenia i obowiązki. W konsekwencji przedstawicielki tego nurtu mogą godzić się, a nawet popierać postulaty, które mogą się wiązać z pewnym ograniczeniem swobód i praw jednostki. Nurt ten może też czerpać $\mathrm{z}$ tradycji politycznego islamu, który zazwyczaj utożsamia się z myślą reprezentowaną przez Braci Muzułmanów i podzielającymi ich ideologię organizacjami.

Feminizm muzułmański, rozumiany jako nurt uznający, że równość kobiet i mężczyzn wynika z zasad religii muzułmańskiej, a wszelkie naruszenia wolności, godności i ograniczenia prowadzące do opresyjnego traktowania kobiet wynikają z patriarchalnego ładu społecznego utrwalonego przez stulecia w społeczeństwach muzułmańskich. Można odnaleźć w nim cechy teologii feministycznej.

Feminizm zs ekularyzow any, który za cel nadrzędny obiera poszanowanie i respektowanie uniwersalnych praw człowieka do integralności fizycznej i psychicznej, godności, szacunku, wolności i zniesienia wszelkich form przymusu czy zniewolenia. W jego ramach dokonuje się krytyki patriarchalnego ładu społecznego, przyzwolenia społeczności muzułmańskich na łamanie praw kobiet. Nurt ten nie ucieka od krytyki islamu ani podstawowych źródeł religii muzułmańskiej. Szczególna troska o poszanowanie wolności jednostki sprawia, że w ramach tego ruchu religia nie odgrywa znaczącej roli. Ten rodzaj feminizmu ma jednak swoje zwolenniczki i ideologów w świecie islamu oraz pośród zachodnich muzułmanów, dlatego też nie sposób go pominąć, mimo że nie wynika z religii muzułmańskiej.

Należy przyjąć, że powyższy podział jest daleki od doskonałości, a działania i twórczość feministek związanych z cywilizacją muzułmańską mogą przyjmować cechy charakterystyczne dla kilku wyodrębnionych nurtów. Problem niedoskonałości wskazanego podziału wynika $\mathrm{z}$ faktu, że próbuje się tu skategoryzować czy wręcz skatalogować pewne dynamiczne zjawiska, często dyktowane potrzebą chwili lub odnoszące się do wielu aspektów egzystencji jednostki czy całego społeczeństwa bądź wspólnoty wiernych. Oczywista wielowątkowość sprawia, że cechy charakterystyczne wyodrębnionych nurtów przenikają się. Wydaje się jednak, że różnice światopoglądowe i doktrynalne pomiędzy muzułmankami działającymi na rzecz równouprawnienia są znaczące. By więc lepiej oddać złożoność ruchów i poglądów feministycznych w łonie islamu, należało dokonać owego podziału.

Podobny podział proponuje jedna z feministek marokańskich Nouzha Gessous Idrissi i wyjaśnia, że „(..) feminizm laicki i muzułmański zakładają różną interpre- 
tację. Pierwszy za punkt odniesienia przyjmuje prawa człowieka, drugi zaś religię"21. Nie stawia też ona znaku równości między terminami „feminizm muzułmański” i „feminizm islamski”, zaznaczając, że pierwszy odnosi się w jej ocenie do kultury, a może szerzej - cywilizacji, drugi zaś bezpośrednio do religii.

\section{Zachodnie działaczki muzułmańskie na rzecz równouprawnienia kobiet}

Muzułmanki żyjące w społeczeństwach zachodnich mogą korzystać z praw i swobód społeczeństw obywatelskich oraz wolności słowa. Dlatego też często działaczki pochodzące z krajów muzułmańskich mieszkają na Zachodzie i tu w miarę nieskrępowanie prowadzą swą działalność, walcząc o prawa kobiet w ramach islamu. Znajomość prawa muzułmańskiego, oparta na świetnej orientacji w tekstach, które stanowią bazę i źródło odwołań dla jurysprudencji, to bezsprzecznie istotny krok do umocnienia pozycji kobiet w ramach tradycji muzułmańskiej. Renegocjowanie pozycji kobiet w społeczeństwach i społeczności muzułmańskich wymaga jednak o wiele więcej. Kolejnym wyzwaniem jest rozpropagowanie lektury tekstu koranicznego z pominięciem perspektywy patriarchalnej. Wraz z upowszechnianiem się islamu w krajach Zachodu coraz więcej konwertytów ingeruje w islam, jego interpretacje i praktyki oraz reformę. Amerykańskiej konwertytce na islam zawdzięcza się spopularyzowanie prokobiecej wersji interpretacji Koranu.

\section{Kobieca lektura Koranu}

Amina Wadud (ur. 1952) jest profesorem islamistyki, od 1972 roku - muzułmanką, córką protestanckiego pastora ${ }^{22}$. Rodzinną tradycję działania w imię i na rzecz religii przeniosła na grunt islamu po dokonaniu konwersji. Amina Wadud wzbudza zainteresowanie, ma wielu zwolenników, ale i zagorzałych przeciwników, wśród których jej postawa oraz poglądy budzą burzliwe emocje. Zasłynęła jako pierwsza kobieta, która wygłosiła piątkową chutbę dla kobiet i mężczyzn. Odbyło się to w RPA, w meczecie w Cape Town w 1994 roku, a wydarzenie miało istotne znaczenie symboliczne, gdyż za jego sprawą rozpoczęto dyskusję na temat przewodniczenia modlitwie dla kongregacji mieszanych przez kobiety, co w konsekwencji mogło otwierać im drogę do pełnienia funkcji imamów. W 2005 roku w Nowym Jorku Amina Wadud przewodniczyła modlitwie, podczas której kobiety i mężczyźni stali ramię w ramię. Działania te wynikały z głębokiego przekonania teolożki o pełnej, nieograniczonej równości muzułmanów. $\mathrm{W}$ islamie widzi ona religię egalitarną, zgodnie z którą czar-

21 N. Guessous Idrissi, op. cit., s. 97.

22 A. Meringolo, Amina Wadud, portrait of a Muslim feminist, ResetDOC, 21.01.2013, www.resetoc. org (dostęp: 22.07.2015). 
noskórzy i biali, kobiety i mężczyźni, osoby homo- i heteroseksualne są sobie równi. Badaczka podkreśla, że celem jej działań jest walka o prawo do muzułmańskiej tożsamości i jednocześnie ludzkiej godności ${ }^{23}$.

Amina Wadud umieszcza swoje badania w szerszym polu badawczym, zaznaczając, że refleksja naukowa nad tekstem koranicznym z kobiecej perspektywy nie była dziedziną szczególnie eksploatowaną, a tę działalność należy sytuować w ramach szerszego zjawiska reinterpretowania, redefiniowania wielu dziedzin i odrzucania normatywnego ludzkiego obrazu świata utrwalonego jedynie z męskiej perspektywy. Jednym z celów przyświecających jej badaniom było zestawienie rzeczywistej sytuacji kobiet w społecznościach muzułmańskich z intencjonalnym obrazem miejsca kobiety w ramach wspólnoty według muzułmańskiej świętej księgi. Role i sytuacja kobiet w społecznościach muzułmańskich są istotnym, a nawet jednym z kluczowych, elementem na drodze świata islamu ku nowoczesności. Wydaje się natomiast, że przyjęcie nowych rozwiązań oraz praktyk społecznych i kroczenie drogą nowoczesności wymaga wspierania się na dawnych, utrwalonych wartościach, tak by nie zburzyć całej tożsamości społecznej. Dlatego też Amina Wadud zdecydowała się na poszukiwanie argumentów świadczących o równości kobiet i mężczyzn w głównym i jedynym niekwestionowanym źródle islamu, czyli w Koranie. We własnej egzegezie korzysta ona z metody interpretacji koranicznej przyjmującej za podstawę założenie, że fragmenty Koranu zostały objawione w określonej czasoprzestrzeni i do niej się odnoszą. Należy czerpać z Koranu wartości, wychwycić intencje, nie zaś powielać konkretne rozwiązania i zachowania. Znaczenie przesuwa się zatem ku intencjom i zasadom, metody działania należy jednak dostosować do współczesnego kontekstu. Koncepcję tę przywołuje wielu reformatorów, sama teolożka wskazuje jednak, że zaczerpnęła ją z pism Fazrula Rahmana ${ }^{24}$.

Równość kobiet i mężczyzn według Koranu badaczka przedstawia, rozpatrując trzy elementy: moment stworzenia, możliwość rozwoju i działania w doczesnym świecie oraz los po śmierci. Komentatorzy Koranu są zgodni co do tego, że w kontekście zmartwychwstania panuje równość, zatem tego wątku Wadud nie rozwija. Podobnie jest w przypadku sądu - i tu kobiety oraz mężczyźni będą podlegać osądowi w ten sam sposób, a zasługujący na nagrodę trafią do raju. Czego dowodzi słusznie przytoczony przez intelektualistkę fragment: „Kto czyni zło, ten otrzyma odpowiednią zapłatę. A kto czyni dobro, mężczyzna czy kobieta, i jest wierzący - tacy wejdą do Ogrodu, gdzie będą mieli zaopatrzenie bez rachunku” (Koran, 40:40).

Tekst koraniczny zawiera jednak również bardziej kontrowersyjne fragmenty. Koran mówi o równym statucie kobiet i mężczyzn przed obliczem Boga, ale można w nim znaleźć fragmenty wskazujące na wyższość mężczyzn nad kobietami, podkreślające konieczność podporządkowania się, ograniczające prawo do rozwodu, aprobujące bicie kobiet. Wydaje się, że w sytuacjach gdy słowa Koranu dość

23 A. Wadud, Islam beyond Patriarchy through Gender Inclusive Qur'anic Analysis, Musawah 2010.

24 A. Wadud, Qur'an and Woman, Oxford University Press, New York-Oxford 1999, s. XI. 
jednoznacznie wskazują, iż to mężczyzna ma uprzywilejowaną pozycję, Amina Wadud powtarza, że Koran powstał wiele stuleci temu i określone fragmenty należy zreinterpretować, gdyż przesłanie przekazane przez Mahometa czasem odnosiło się do ówczesnych realiów. Badaczka wyraża przekonanie, że zdecydowaną różnicę widać między surami mekkańskimi i medyńskimi. O ile wersety pierwszego okresu potwierdzają doktrynalny egalitaryzm, o tyle wraz z przyjęciem funkcji przywódcy wspólnoty przez Mahometa w Medynie zmienił się charakter objawień, a w związku z tym, że odnosiły się one do konkretnych sytuacji w konkretnych czasach, nie przystają do współczesności. Odpowiadają natomiast realiom VII wieku na Półwyspie Arabskim, gdzie panował patriarchat. Wadud zaznacza jednocześnie, że pojawienie się islamu i nauczanie Mahometa poprawiło sytuację kobiet i było ówcześnie postępowe. „W medyńskim okresie objawienia wprowadzane reformy społeczne były bezpośrednio związane z ówcześnie obowiązującymi praktykami. $Z$ tej perspektywy warto wskazać, że większość reform przynosiła poprawę sytuacji kobiet”25 - pisze intelektualistka.

Krytycznie można zatem uznać, że Wadud traktuje kwestię dość wybiórczo i jeśli wybrany werset godzi w godność kobiety lub sankcjonuje nierówny status, to traktuje go jako osadzony w epoce Proroka i odnoszący się wyłącznie do danego okresu. Jeśli zaś fragment traktuje kobiety równie dobrze jak mężczyzn, to należy go uznać za niepodważalny dowód na równość płci wywiedzioną z Koranu, a więc wieczną i niekwestionowaną. Zwłaszcza że całość przekazu świętej księgi wspiera wizję egalitarną układów międzyludzkich, a właśnie całościowe ujęcie przekazu koranicznego postuluje działaczka i przytacza słowa: „Wy wierzycie w Księgę w całości” (Koran, $3: 119)$.

\section{Historyczno-społeczne uwarunkowania równouprawnienia}

$\mathrm{Z}$ nieco innej perspektywy kwestie równouprawnienia rozpatruje przywoływana już Leila Ahmed, która jest z pochodzenia Egipcjanką, ale mieszka i pracuje w Stanach Zjednoczonych. Swoje poglądy i analizy dotyczące islamu oraz równouprawnienia przedstawia w wielu książkach i artykułach naukowych. Koncentruje się na uwarunkowaniach historyczno-społecznych. Ważnym jej dziełem jest Women and Gender in Islam: Historical Roots of a Modern Debate, gdzie podejmuje analizę pozycji i roli kobiet z perspektywy historycznej i przedstawia sytuację społeczną kobiet w świecie przedmuzułmańskim, w okresie kształtowania się islamu, aż po pojawienie się i rozwój feminizmu w kręgu cywilizacji muzułmańskiej. Leila Ahmed szeroko opisuje, w jaki sposób w XIX wieku ideologizowanie i usprawiedliwianie kolonizacji przywłaszczyło sobie retorykę rodzącego się ruchu feministycznego i skierowało go przeciwko społeczeństwom muzułmańskim, antagonizując tradycję muzułmańską i szeroko zakrojony ruch równouprawnienia kobiet, ustawiwszy go w opozycji do

25 A. Wadud, Inside the Gender Jihad: Woman's Reform in Islam, Oneworld, Oxford 2006, s. 3. 
tradycyjnych wartości kolonizowanego świata islamu ${ }^{26}$. Podkreśla jednocześnie, że dla kobiet w ramach cywilizacji muzułmańskiej konieczne jest wypracowanie własnej formuły „uporania się" z patriarchalnym i opresyjnym systemem społecznym, obyczajowym i politycznym, nie zaś przyjęcie gotowego systemu wypracowanego $\mathrm{w}$ toku ewolucji innych społeczeństw, i powołuje się tu na przykład rozwoju feminizmu zachodniego. Przypomina, że feministki zachodnie nie odrzuciły całej historii i dziedzictwa Europy, mimo iż wiele kobiet zginęło na stosach. Nie głosiły postulatu całkowitego odrzucenia zachodniego systemu społecznego, a zaangażowały się w ,krytyczną i konstruktywną analizę tego dziedzictwa na własnych warunkach"27. Osadzenie we własnej kulturze jest głęboko zakorzenione w psychice i całkowite odrzucenie takiego systemu kulturowego wiązałoby się z przemodelowaniem tożsamości jednostki i całej grupy. Do tego dążyła retoryka kolonialna i w ten sposób nacjonalizm, feminizm oraz zagadnienia polityczne i kulturowe, a nawet ekonomiczne zostały połączone ${ }^{28}$ - uważa L. Ahmed.

\section{Współczesne wyzwolone europejskie muzułmanki}

Wpływ kolonializmu na rolę kobiet w świecie islamu i rozwój oraz stosunek społeczny do feminizmu muzułmańskiego bada też Zahra Ali - Francuzka pochodząca z Iraku, która aktywnie działa na rzecz równouprawnienia pozostającego w zgodzie z religią muzułmańską. Podobnie jak dla Leili Ahmed, także dla tej intelektualistki pretekstem do wielu rozważań staje się zagadnienie chusty muzułmańskiej, zwłaszcza że we Francji, gdzie żyje i pracuje, temat ten wzbudza wciąż wiele kontrowersji. W swej działalności naukowej i społecznej Zahra Ali zwraca uwagę, że współczesne, aktywne zawodowo i społecznie muzułmanki zaangażowane w swoją wiarę i religijność we Francji, ale i w większości innych krajów europejskich są narażone na trudności płynące z dwóch źródeł.

Pierwszym jest opór ich własnego środowiska wobec idei równościowych, drugim zaś społeczeństwo kraju, w którym żyją, widzące w nich - szczególnie po głośnych zamachach terrorystycznych i spektakularnych aktach przemocy organizowanych w imię islamu - radykalne fundamentalistki, które mogą stanowić zagrożenie. Jednak i w ramach samej wspólnoty muzułmańskiej aktywne społecznie działaczki czy kobiety robiące karierę mogą spotkać się z krytyką za odejście od utrwalonej tradycją roli kobiety w społeczności muzułmańskiej. Zahra Ali zaznacza przy tym, że poglądy i postawa tych kobiet nie wynikają z edukacji religijnej, jaką otrzymały w rodzinie, lecz są raczej wynikiem własnych poszukiwań, działalności w ramach różnych stowarzyszeń i organizacji obywatelskich, czasem pewnego rozczarowania nimi i potrzeby wypracowania własnego dyskursu dotyczącego islamu, miejsca ko-

6 L. Ahmed, op. cit., s. 237.

Ibidem, s. 128.

Ibidem, s. 216. 
biety w rodzinie, społeczności muzułmańskiej i w niemuzułmańskim społeczeństwie przyjmującym ${ }^{29}$. Model ich zaangażowania zdefiniowano trafnie jako „religijność born again ustawioną w opozycji do tradycjonalizmu, często zindywidualizowaną, o podbudowie intelektualnej, która najczęściej zapewnia im autorytet w rodzinie"30. W konsekwencji ich poszukiwania zmierzają ku teologii ujmującej islam jako religię egalitarną.

\section{Równouprawnienie a zaangażowanie społeczne}

Zupełnie inny charakter ma działalność francuskiej aktywistki Fadeli Amary, która wychowała się w Clermont-Ferrand, w dzielnicy narażonej na nierówność szans, gdzie tradycje patriarchalne przyczyniają się do zniewolenia kobiet pochodzących z muzułmańskich środowisk imigranckich. Wydaje się, że biografia aktywistki w dużej mierze była zdeterminowana tragiczną śmiercią młodszego brata Amary. Zginął on w wypadku samochodowym, potrącony przez pijanego kierowcę. Przybyła na miejsce zdarzenia policja poniżała rodzinę ofiary, odwołując się do ich pochodzenia, a sprawca nie poniósł konsekwencji. Fadela Amara, choć nie uczestniczyła w historycznym Marszu na rzecz Równości i przeciw Dyskryminacji (fr. Marche des Beurs) w 1983 roku, który zjednoczył środowiska imigranckie w proteście przeciwko rasizmowi i dyskryminacji, odwołuje się jednak i korzysta z jego silnego przekazu ${ }^{31}$. Amara znała dobrze realia życia osiedli zamieszkanych przez imigrantów i ich potomków. Jako córka w wielodzietnej tradycyjnej rodzinie doznawała nierównego traktowania - ograniczenia i zakazy w większym stopniu dotyczyły jej niż braci ${ }^{32}$. Już w wieku 16 lat angażowała się w działalność obywatelską. Wtedy z sukcesem zorganizowała protest wobec wyburzeniu budynku, gdzie mieszkała wraz z rodziną. Rok później przekonywała młodych mieszkańców przedmieść do udziału w wyborach. W 2002 roku z inicjatywy Fadeli Amary odbył się na Sorbonie pierwszy kongres młodych kobiet z gett. Blisko 300 uczestniczek z całej Francji dyskutowało na temat przemocy, jakiej doświadczają, i kulturowych ram, które tę przemoc sankcjonują i czynią bezkarną ${ }^{33}$. Frustracja wywołana bezrobociem i brakiem szans na godne życie w połączeniu z patriarchalną wizją ładu społecznego odziedziczoną z krajów pochodzenia rodziny oraz rozwijającą się subkulturą gangów sprawiają, że od blisko 30 lat dziewczęta z gett nie mogą czuć się bezpiecznie. Nieodpowiedni strój czy makijaż mogą stać się pretekstem do pobicia, okaleczenia, a nawet gwałtu lub gwałtu zbiorowego (fr. tournante) ${ }^{34}$. W październiku 2002 roku Sohane Benzia-

29 Z. Ali, Des musulmanes en France: féminisme islamique et nouvelles formes de l'engagement pieux, „Religioscope. Études et analyses” 2012, no. 27, s. 2.

30 Ibidem.

31 C. Amar, Fadela Amara. Le Destin d'une femme, Hachette, Paris 2009, s. 12.

32 F. Amara, S. Zappi, Ni putes ni soumises, La Découverte, Paris 2004, s. 14-17.

33 I. Lichter, Muslim Women Reformers, Prometheus Books, New York 2009, s. 118.

34 S. Bellil, Dans l'enfer des tournantes, Gallimard Éducation, Paris 2002, s. 18 i n. 
ne została spalona żywcem, padając ofiarą jednego z gangów „strzegących cnoty kobiet”. Zbrodnia odbiła się szerokim echem wśród francuskiej opinii publicznej, organizowano marsze i spotkania, by uczcić pamięć zamordowanej. Wydarzenie to było bezpośrednim impulsem, który skłonił Fadelę Amarę do założenia i kierowania organizacją działającą na rzecz kobiet z gett, a hasło marszu ku czci Sohane Benziane stało się nazwą tego ruchu. Ni putes ni soumises (Ani dziwki, ani uległe) pomagała młodym kobietom wyrwać się od rodziny, uniknąć drastycznych konsekwencji tzw. splamienia honoru rodziny. Z czasem organizacja rozwinęła swoją działalność. Obecnie jest jedną z najprężniej działających we Francji. NPNS ma swoje oddziały w Pakistanie, Kanadzie, Szwecji, Belgii, Hiszpanii i Szwajcarii ${ }^{35}$.

Dzięki swej działalności Fadela Amara stała się osobą publiczną, która odważnie mówi o bolączkach i niesprawiedliwościach, jakich doświadczają osoby z nieuprzywilejowanych grup społecznych. Wyraźnie wskazuje, że islam w swej obecnej formule jest narzędziem wykorzystywanym do ograniczania wolności, przede wszystkim kobiet, ale i osób LGBT. W 2007 roku Fadela Amara objęła urząd sekretarza stanu do spraw polityki miejskiej i pełniła tę funkcję przez dwa lata. Wiele pisano wtedy o marionetkowym charakterze beurette de service (fasadowej reprezentantki środowisk arabsko-muzułmańskich w służbie rządowych oficjeli).

Tematykę równouprawnienia w kontekście religii muzułmańskiej podejmuje regularnie, a swoim przekonaniom daje wyraz w debatach publicznych i wywiadach. Definiuje siebie jako praktykującą muzułmankę: „Prowadząc działalność w ramach organizacji pozarządowych, nigdy nie ukrywałam, że jestem praktykującą muzułmanką. To jest jednak moja prywatna sprawa i nie przeszkadza mi być laickim politykiem"36 - mówi w jednym z wywiadów. Jednoznacznie deklarowała swoje poparcie dla ustawy zakazującej ostentacyjnych znaków religijnych w miejscach administracji publicznej.

Fadela Amara jest przykładem wyzwolonej kobiety, muzułmanki, Europejki pochodzącej z Maghrebu, reprezentującej pokolenie poimigracyjne, która wykorzystując możliwości, jakie daje społeczeństwo obywatelskie, zwalcza praktyczne przejawy patriarchatu czerpiącego legitymizację z religii.

$$
* * *
$$

Dynamika zmian społecznych wynikająca z procesów globalizacji, kurczenie się świata i pewna homogenizacja postaw, norm i oczekiwań społecznych - wszystko to sprawia, że powstaje coraz więcej organizacji i instytucji działających na rzecz równouprawnienia. Intelektualiści muzułmańscy widzą konieczność reformowania czy też reinterpretowania islamu. Wydaje się, że nieodłącznym elementem takiej refor-

35 Zob. http://www.npns.fr/l-association-ni-putes-ni-soumises/presentation/ (dostęp: 27.08.2015).

36 Fadela Amara: je suis musulmane pratiquante et lä̈que en politique, TSA, 3.04.2008, http://archives. tsa-algerie.com/politique/fadela-amara-je-suis-musulmane-pratiquante-et-laique-en-politique_3125. html (dostęp: 27.08.2015). 
my jest status i pozycja kobiety. Wielowiekowy, utrwalony patriarchalny ład społeczny jest rozpowszechniony w społeczeństwach państw muzułmańskich, a także w części zachodnich społeczności muzułmańskich, nie jest jednak jedyną postawą społecznie reprezentowaną. Coraz więcej muzułmanek głośno upomina się o swoje prawa, a wielość przejawów dyskryminacji wymusza działania na wielu płaszczyznach. Przedstawione działaczki reprezentują różne środowiska i różnorodne formy działania, celem zaś tego opracowania było ukazanie zróżnicowanych podejść i sposobów działania w ramach feminizmu muzułmańskiego na Zachodzie. Lista muzułmańskich feministek i aktywistek jest długa, a niniejszy artykuł nie aspiruje do zaprezentowania ich wszystkich. Chodziło raczej o zobrazowanie charakterystycznych postaw i metod działania.

\section{Bibliografia}

Abbas A., Maśko A. (red.), W kręgu zagadnień świata arabskiego, Uniwersytet im. Adama Mickiewicza, Poznań 2015.

Ahmed L., Women and Gender in Islam: Historical Roots of a Modern Debate, Yale University Press, New Haven 1992.

Ali Z., Des musulmanes en France: féminisme islamique et nouvelles formes de l'engagement pieux, „Religioscope. Études et analyses” 2012, no. 27.

Amar C., Fadela Amara. Le Destin d'une femme, Hachette, Paris 2009.

Amara F., Zappi S., Ni putes ni soumises, La Découverte, Paris 2004.

Amin Q., Tahrir al-Mar'a, al-Qahira 1970.

Bellil S., Dans l'enfer des tournantes, Gallimard Éducation, Paris 2002.

Brzezińska J., Islam i feminizm - ruch kobiet $w$ Egipcie na rzecz równouprawnienia kobiet, „Acta Universitatis Lodziensis. Folia Sociologica” 2011, nr 39.

Dziekan M.M., Kończak I. (red.), Kobiety Bliskiego Wschodu, Wydawnictwo Ibidem, Łódź 2005.

Guessous Idrissi N., Féminisme musulman, féminisme islamique ou féminisme en terre d'islam. L'exemple du Maroc, w: Existe-t-il un féminisme musulman?, L'Harmattan, Paris 2007.

Hannam J., Feminizm, przeł. A. Kaflińska, Zysk i S-ka, Poznań 2010.

Kowalska B., Kobiety, rozwój, obywatelstwo w Haszymidzkim Królestwie Jordanii, Wydawnictwo Uniwersytetu Jagiellońskiego, Kraków 2013.

Kowalska B., Kontrola kobiecej cielesności. Refleksje o orientalizmie, fundamentalizmie i zastonie, w: J. Bator, A. Wieczorkiewicz (red.), Ucieleśnienie II. Między ciałem a tekstem, Wydawnictwo IFiS PAN, Warszawa 2008.

Kowalska B., Płeć, islam a zmiana społeczna. Dylematy współczesnego dyskursu emancypacyjnego na Bliskim Wschodzie, w: A. Kapiszewski (red.), Świat arabski w procesie przemian. Zmiany społeczne i kulturowe oraz reformy polityczne, Księgarnia Akademicka, Kraków 2008.

Lichter I., Muslim Women Reformers, Prometheus Books, New York 2009.

Machut-Mendecka E., Archetypy islamu, Wydawnictwo Psychologii i Kultury Eneteia, Warszawa 2006.

Mernissi F., Beyond the Veil, Indiana University Press, Bloomington 1987. 
Nalborczyk A.S., Dżihad genderowy, „Więź” 2014, nr 1 (655).

Pachniak K. (red.), Kobieta w literaturze i kulturze Egiptu, Katedra Arabistyki i Islamistyki Uniwersytet Warszawski, Warszawa 2016.

Szczepankiewicz-Rudzka E., An-nisayat - różne wymiary feminizmu w świecie islamu, „Kultura i Wartości" 2014, nr 1 (9).

Wadud A., Inside the Gender Jihad: Woman's Reform in Islam, Oneworld, Oxford 2006.

Wadud A., Islam beyond Patriarchy through Gender Inclusive Qur'anic Analysis, Musawah 2010.

Wadud A., Qur'an and Woman, Oxford University Press, New York-Oxford 1999.

\section{Źródła internetowe}

Abisaab M., Abisaab M. J., A Century after Qasim Amin: Fictive Kinship and Historical Uses of 'Tahrir al-Mara', http://www.aljadid.com/content/century-after-qasim-amin-fictive-kinship-and-historical-uses-tahrir-al-mara\#sthash.oZgWrFZP.dpuf (dostęp: 15.11.2014).

Bobako M., Feminizm islamski. Niechciane dziecko islamu politycznego, „Praktyka Teoretyczna" 2013, nr 2 (8), www.praktykateoretyczna.pl (dostęp: 22.07.2015).

Fadela Amara: je suis musulmane pratiquante et läque en politique, TSA, 3.04.2008, http:// archives.tsa-algerie.com/politique/fadela-amara-je-suis-musulmane-pratiquante-et-laique-en-politique_3125.html (dostęp: 27.08.2015).

http://www.npns.fr/l-association-ni-putes-ni-soumises/presentation/ (dostęp: 27.08.2015).

Meringolo A., Amina Wadud, portrait of a Muslim feminist, ResetDOC, 21.01.2013, www. resetoc.org (dostęp: 22.07.2015).

Wąs A., Kobieta w islamie, Wiara.pl, 10.04.2009, http://religie.wiara.pl/doc/472173.Kobieta-w-islamie (dostęp: 21.11.2014). 